\title{
EVALUATING THE USE OF PERSONAL NETWORKS TO CIRCUMVENT FORMAL PROCESSES: A CASE STUDY OF VRUZKI IN BULGARIA
}

Colin C. Williams, Junhong Yang

\begin{abstract}
The aim of this paper is to evaluate the prevalence and distribution of the use of personal connections to circumvent formal procedures by soliciting favours for and from others, known as vruzki, and how this can be explained and tackled. Reporting data from 2,005 face-to-face interviews conducted in late 2015 in Bulgaria, the finding is that 30 per cent of respondents had used vruzki in the 12 months prior to the survey, particularly when accessing medical services and finding a job. Estimating a logit model and then calculating the marginal effects, the population groups significantly more likely to have used vruzki are those whose norms, values and beliefs are not in symmetry with the formal laws and regulations, perceiving the penalties and detection risks as higher, those reporting their financial situation as very comfortable, and the highest income groups, but also younger people, the unemployed, and those living in larger households. The paper concludes by discussing the theoretical and policy implications along with the future research required.
\end{abstract}

Keywords: informal sector; corruption; cronyism; nepotism; Bulgaria; South-East Europe

JEL classification: $\mathrm{H} 26, \mathrm{~J} 46, \mathrm{~K} 34, \mathrm{~K} 42,017$

\section{INTRODUCTION}

The use of personal connections to circumvent formal procedures by soliciting personal favours for and from others prevails in all societies to varying degrees. This is known as guanxi in China (Chen et al. 2011, 2013; Luo 2011; Yang and Wang 2011), wasta in the Arab world (Smith et al. 2011), jeitinho in Brazil (Ardichvili et al. 2010; Ferreira et al. 2012), 'pulling strings' in English speaking countries (Smith et al. 2012), blat in post-Soviet spaces (Ledeneva 2008, 2009, 2013), vrski in FYR Macedonia, veze in Serbia, Croatia, and Bosnia and Herzegovina, and vruzki in Bulgaria. The reason this practice is important to study is because it hinders the development of meritocratic processes and results in the persistence of cronyism, nepotism and corruption. The aim of this paper is to contribute to the advancement of knowledge on this practice by evaluating the prevalence and distribution of vruzki in Bulgaria and discusses how it can be explained and tackled. Until now, no known empirical studies have been undertaken of vruzki. The intention in this paper is to start to fill this gap.

Colin C. Williams, PhD

Professor of Public Policy

Sheffield University Management School (SUMS)

University of Sheffield

E-mail: C.C.Williams@sheffield.ac.uk

Junhong Yang, PhD

Lecturer in Finance

Sheffield University Management School (SUMS)

University of Sheffield

E-mail: junhong.yang@sheffield.ac.uk 
In the first section of this paper, therefore, the existing literature will be reviewed on the use of personal networks to circumvent formal procedures to get things done. This will reveal that despite the use of personal connections to circumvent formal procedures being studied elsewhere in the world, there has been very little focus upon its prevalence and usage in South-East Europe. To fill this gap, the second section introduces a study of the use of vruzki in Bulgaria based on 2,005 face-to-face interviews conducted in late 2015. The third section then reports the findings. This will display the prevalence of vruzki and who uses it, along with how it can be explained and tackled, by estimating a logit model and then calculating the marginal effects. The final section then draws some conclusions and explores how these corrupt practices can be eradicated.

\section{USING PERSONAL CONNECTIONS TO CIRCUVENT FORMAL PROCEDURES}

All countries have to produce, distribute and allocate goods and services. Three separate ways of doing this are commonly differentiated, namely the 'market' (private sector), 'state' (public sector) and 'community' (informal or third) sectors (Giddens 1998; Gough 2000; Polanyi 1944; Thompson et al. 1991). The notion that these are separate realms is brought starkly into the question when examining the use of personal networks to circumvent formal procedures because it reveals the permeation of the private and public sectors by the informal realm.

Social networks have been recognised as resources that populations draw upon to meet their needs ever since the studies by Stack (1974) and Young and Wilmott (1975), which emphasised the beneficial effects of the help provided by and for close ties. In recent decades, moreover, the social capital literature has also highlighted the beneficial effects arising when ties are forged between people who do not know each other very well (Putnam 2000), or what Granovetter (1973) calls the 'strength of weak ties'. The resulting emphasis has been on the positive effects of the help provided by and for not only close ties (i.e. 'bonding' social capital) but also the weaker ties of people who do not know each other well (i.e. 'bridging' social capital) (Gittell and Vidal 1998; Putnam 2000).

A smaller literature, however, has highlighted how social capital also has a more negative 'darker side' (Ayios et al. 2014; Garigiulo and Benassi 1997; Gu et al. 2008; Putze, 1997; Schulman and Anderson 2009). This has shown how the use of social networks can result in cronyism (i.e., helping acquaintances and friends), nepotism (i.e., favouritism to kin), and/or corruption (i.e., the use of public office for private gain), as well as hinder meritocracy (Ayios et al. 2014).

Exemplifying this 'dark side' of social capital is the use of social networks to circumvent formal procedures. In China, guanxi ('connections') describes a network of contacts from whom favours can be received in terms of accessing a good or service or bypassing bureaucratic procedures, which must then be reciprocated in the future (Hsuing 2013; Mikhailova and Worm 2003). Indeed, it is seen as extensively used in Chinese business and culture (Luo 2011; Luo et al. 2011; Shou et al. 2014; Zhan 2012). Although a few studies draw attention to its negative effects, such as when nepotism prevails in job recruitment (Chen et al. 2011), most studies simply see it as an unavoidable feature that needs recognising when doing business in China (Chen et al. 2013; Munro et al. 2013; Yang and Wang 2011; Zhuang et al. 2010).

In Arab countries meanwhile, wasta is the most common term used to describe connections rooted in family and kinship ties that are used to sidestep formal procedures (Hutchings and Weir, 2006; Smith et al., 2011), or ma'arifa in North African nations such as Tunisia, Algeria and Morocco (Mellahi and Wood 2006; Yahiaoui and Zoubir 2006). Most studies in Arab countries again reveal a neutral or positive attitude towards its usage (Bailey 2012; Barnett et al. 2013; Kilani and Sakijha 2002; Mohamed and Mohamed 2011; Tlaiss and Kauser 2011), with a 'no nepotism' policy being absent in the Arab business world and favouritism, rather than merit, widely employed in hiring and promotion decisions.

In Brazil and other Portuguese speaking countries, meanwhile, the term commonly used is either pistolão ('contacts') or jeitinho ('find a way') when referring to circumventing formal procedures by the use of connections which again, is viewed as a helpful coping practice (Ardichvili et al. 2010). English-speaking countries employ the term 'pulling strings', which refers to favours obtained through often longstanding links with influential persons, often derived from family connections or shared schooling (Smith et al. 2012). A cross-national comparative study of attitudes reveals English people view the use of connections to circumvent formal procedures even more positively than the Chinese, Arabs and Brazilians (Smith et al. 2012).

In the post-Soviet world, meanwhile, the use of personal networks to obtain goods and services in short supply, or circumvent formal procedures, is known as blat (Arnstberg and Boren 2003; Ledeneva 2006, 2008, 2009, 2013; Mikhailova and Worm 2003; Smith et al. 2011). Under the Soviet system, money had relatively 
little value given the shortage of goods to purchase. It was thus more important to have a wide network of friends and acquaintances to call upon in times of need, and a commonly heard phrase during the Soviet period was 'it is better to have a hundred friends than a hundred roubles'. Blat networks thus 'loosened up the rigid constraints of the political regime' (Ledeneva 2009 , p. 257) and was used to negotiate almost all aspects of life from acquiring everyday goods such as food, and periodic events such as holidays, to lifecycle events such as obtaining kindergarten and university places. Thus, blat in its traditional meaning in Soviet society was widely viewed in a positive or neutral manner since it helped people to cope with the inefficiencies of the command economy. Indeed, blat was an important status symbol and source of pride and prestige for those able to help others (Williams et al. 2013). Few therefore regarded such friendly help as being in anyway a corrupt practice (Williams et al. 2013). The consensus in the literature is that the use of connections to gain preferential access to services persists in post-Soviet societies, but that connections and access to assets are increasingly treated as a commodity, with gifts and/or money received and given for this (Ledeneva 2009, 2013 Onoshchenko and Williams 2013, Williams and Onoshchenko 2014a,b). Al Ramahi (2008) has noted a similar trend in relation to wasta. Indeed, this is reflected in recent studies. Take, for example, the study of informality in health services. Rather than study blat, studies now focus upon the use of informal payments to gain access to medical services (Gordeev et al. 2014; Kaitelidou et al. 2012; Stepurko et al. 2013; Williams et al. 2016).

In South-East Europe, meanwhile, such connections are variously referred to as vrski in Macedonian, veze in Serbia and vruzki in Bulgaria. Until now, not only is there hardly any scholarly literature, with the notable exception of Chavdarova (2013) who has discussed vruzki, but there are also no known empirical studies of the prevalence and usage of connections in South-East Europe. Despite this, the use of connections to circumvent formal procedures is widely discussed in popular culture and is often at the heart of many critiques by Bulgarians of how their society operates. Such connections are seen to help create significant privileges for individuals connected to the ruling powers and state apparatus, as well as to private firms and their owners. However, it is also sometimes seen more positively as a way of getting things done. Until now, nevertheless, empirical studies of the prevalence and distribution of vruzki in contemporary Bulgarian society are notable by their absence. So too are studies which evaluate how this practice might be explained and tackled.
To explain the use of connections and to consider ways of tackling this practice, one way forward is to apply to the study of vruzki the theoretical perspectives used to explain and tackle undeclared work. As the literature on undeclared work, two dominant perspectives have been adopted (Williams and Horodnic 2015a,b, 2017). First, a rational economic actor approach has argued that people weigh up the costs and benefits of engaging in such activities and decide to do so when the benefits outweigh the costs (Allingham and Sandmo, 1972). The resultant policy approach, which has been widely adopted, is to raise the costs by increasing the perceived and/or actual penalties and risks of detection. In recent years, however, there has been recognition that many citizens do not engage in such illicit activities even when the benefits outweigh the costs, and this has resulted in the emergence of a social actor approach. Viewed through the lens of institutional theory (Baumol and Blinder 2008; North 1990), every society is seen to possess both formal institutions, namely laws and regulations defining the legal rules of the game, as well as informal institutions, namely 'socially shared rules, usually unwritten, that are created, communicated and enforced outside of officially sanctioned channels' (Helmke and Levitsky 2004, p. 727). From this viewpoint, the greater is the asymmetry between the formal institutions (i.e., 'state morale') and informal institutions (i.e., 'citizen morale'), the greater will be the participation in such illicit activities (Williams and Franic 2015; Williams and Horodnic 2015a,b, 2017; Williams et al. 2014). Indeed, this has been recently highlighted to be the case in the specific context of Bulgaria, albeit only in relation to entrepreneurs (Williams and Vorley, 2016). To tackle illicit activities, therefore, there is a need to reduce the level of asymmetry between the formal and informal institutions. Here, for the first time, these theoretical perspectives can be applied to study of the use of personal connections using a case study of vruzki in Bulgaria.

\section{DATA AND VARIABLES Data}

To evaluate the prevalence and distribution of vru$z k i$ in contemporary Bulgarian society, as well as how it might be explained and tackled, data is reported from 2,005 face-to-face interviews conducted in Bulgaria in late 2015. This household survey included questions on whether respondents used and provided favours to circumvent formal procedures, and the spheres in which they did so, as well as questions on their perceptions regarding the penalties and risks of 
detection when participating in illicit activities, and whether they view engagement in illicit activities as acceptable so as to measure the level of symmetry between their morale and the state morale of formal institutions. To collect this data, a multi-stage random (probability) sampling methodology was used to ensure that on the issues of gender, age, region and locality size, the national level sample, as well as each level of the sample, was representative in proportion to its population size. In every household the 'closest birthday' rule was applied to select respondents, while every subsequent address was determined by the standard 'random route' procedure.

\section{Variables}

To evaluate the use of vruzki, the dependent variable used is a dummy variable with recorded value 1 for respondents who answered 'yes' to the question: "Have you in the last 12 months asked anyone for a favour/help using connections in any of the following spheres?", and zero otherwise if they had not used vruzki. The spheres analysed were: medical services (skipping queue, getting better examination, surgery); solving problems with the law enforcing authorities (traffic police, customs); finding a job; education (places in higher education/ obtaining degree/diploma etc.); legal services and courts; everyday services at better quality or better price (e.g., bank services, hairdressers); repairs (housing, garages, car); tickets for events, theatre, concerts; hobbies and entertainment, tourist resorts, travel tickets; consumer goods excluding foodstuffs; communicating with local authorities on business matters (e.g. delaying tax payment); foodstuffs; speeding up bureaucratic procedures (e.g. at the municipal hall), and any other realms. This enabled the degree to which it is used in each of these spheres to be analysed.

To evaluate the distribution of vruzki, meanwhile, the following independent variables were analysed, derived from wider studies evaluating the associated issue of the important socio-demographic and socioeconomic variables influencing participation in undeclared work (Williams and Horodnic 2015a,b, 2016; Williams and Padmore 2013a,b):

- Gender: a dummy variable with value 0 for women and 1 for men.

- Age: an interval variable indicating the exact age of the respondent.

- Marital status: a categorical variable with value 1 for married/remarried, value 2 for cohabiting and value 3 for single/divorced.

- Household size: a categorical variable with value
0 for one person, value 1 for two persons, value 3 for three persons, value 4 for four or more persons.

- Occupation: a categorical variable with value 0 for unemployed, value 1 for self-employed, value 2 for employed and value 3 for other (retired, students, disabled, etc).

- Financial situation: a categorical variable with value 0 for no money problems, value 1 for just comfortable, value 2 for maintaining, and value 3 for struggling.

- Net income: a categorical variable of the net income of individuals with value 0 for no income, value 1 for less than $€ 350$ per month, value 2 for $€ 350-700$, value 3 for $€ 701-1000$, value 4 for $€ 1001-1300$, value 5 for $€ 1301-1800$ and value 6 for more than $€ 1800$ per month.

- Type of locality: a categorical variable with value 0 for rural area or village, value 1 for small or middle-sized town, value 2 for large urban area.

- Regions: a categorical variable with value 0 for North Central, value 1 for North Eastern, value 2 for North Western, value 3 for South Central, value 4 for South Eastern, and value 5 for South Western.

To evaluate the competing ways of explaining and tackling vruzki, three explanatory variables were used. Firstly, to evaluate whether the perceived risk of detection influences engagement, a dummy variable was used describing the perceived risk of being detected, with value 0 for a very small and fairly small risk, value 1 for fairly high risk and very high risk. Secondly, to evaluate how penalties are associated with participation, a dummy variable was employed, describing the expected sanctions, with value 0 for those asserting that the normal tax or social security contributions would be due, value 1 for those stating that the normal tax or social security contributions due, plus there would be a fine or for imprisonment.

Third and finally, to evaluate the association between engagement in vruzki and the level of institutional asymmetry, an interval variable was used by constructing an index of self-reported attitudes towards the acceptability of various illicit activities based on a 10-point Likert scale. Rather than use a single question to assess the gap between citizen and state morale (i.e., the level of institutional asymmetry), this survey uses a range of questions by asking the following:

Now I would like to know how you would rate various actions or behaviours. For each of them, please tell me to what extent you find it acceptable or not. Please use the following scale: "1" means that you 
find it absolutely unacceptable and " 10 " means that you find it absolutely acceptable: (1) someone receives welfare payments without entitlement; (2) an individual is hired by a household for work and $\mathrm{s} /$ he does not declare the payment received to the tax or social security authorities even though it should be declared; (3) A firm is hired by a household for work and it does not declare the payment received to the tax or social security authorities; (4) a firm is hired by another firm for work and it does not declare its activities to the tax or social security authorities; (5) a firm hires an individual and all or a part of the wages paid to him \her are not officially declared and (6) someone evades taxes by not declaring or only partially declaring their income.

Collating the responses to these six questions, and giving equal weighting to each response, an aggregate 'citizen-state morale alignment index' is constructed for each individual. The Cronbach's Alpha coefficient of the scale is 0.87 which shows a good internal consistency of the scale (Kline 2000). The index is represented here in the 10-point Likert scale original format. The lower the index value, the higher is the citizen morale (i.e., the more aligned is citizen morale with state morale).

Given that there were a considerable number of missing values and inconclusive answers (i.e., refusal and 'don't know') across the dependent and independent variables, multiple imputation was used to predict the values. This is done using a system of chained equations for each variable with missing values, with 50 imputations simulated for each missing value. Furthermore, population weights are applied based on age and gender to correct for under- and over-representation in the sample. Table 1 provides a summary of the key variables that includes the number of observations, mean values, and missing data. None of the independent variables are highly correlated.

To analyse its usage in different realms, descriptive statistics are presented. To evaluate who is significantly more likely to use vruzki in contemporary Bulgarian society, as well as the explanations and how it might be tackled, a logit model is estimated and then the marginal effects calculated. Below, the results are reported.

\section{FINDINGS}

Examining the nationally representative sample of 2,005 respondents interviewed face-to-face in late 2015 in Bulgaria, just 5 per cent held the view that the use of vruzki was not important in order to get things done. Some 21 per cent asserted that it is somewhat important, 41 per cent that it is important, and 33 per cent that it is very important. This is reflected in the findings on whether they used vruzki to get things done. Some 30 per cent of all respondents surveyed had used vruzki in the last 12 months in order to circumvent formal processes.

Analysing the spheres in which the respondents had used vruzki to get things done, 13 per cent had used vruzki to gain access to medical services (e.g., jumping the queue, getting a better examination), 12 per cent to find a job, 8 per cent to get repairs (e.g., to their home or car), 6 per cent to gain access to everyday services such as hairdressers and bank services, 4 per cent to acquire food, 4 per cent to gain access to

Table 1: Summary statistics of key variables.

\begin{tabular}{|c|c|c|c|c|c|c|}
\hline Variable & Mean & SD & Min & Median & Max & $\mathrm{N}$ (missing) \\
\hline Use vruzki & 0.300 & 0.460 & 0 & 0 & 1 & 49 \\
\hline Tax morale & 1.93 & 1.85 & 0 & 1.3 & 10 & 116 \\
\hline Detection risk & 0.26 & 0.44 & 0 & 0 & 1 & 321 \\
\hline Expected sanctions & 0.62 & 0.49 & 0 & 1 & 1 & 545 \\
\hline Women & 0.52 & 0.5 & 0 & 1 & 1 & 0 \\
\hline Age & 47.68 & 17.32 & 15 & 48 & 85 & 0 \\
\hline Marital status & 1.71 & 0.9 & 1 & 1 & 3 & 16 \\
\hline Household Size & 2.67 & 1.02 & 1 & 3 & 4 & 0 \\
\hline Employment status & 3.09 & 0.9 & 1 & 3 & 4 & 0 \\
\hline Financial situation & 3.15 & 0.71 & 1 & 3 & 4 & 21 \\
\hline Personal income & 2.72 & 1.08 & 1 & 3 & 7 & 105 \\
\hline Locality type & 2.2 & 0.86 & 1 & 2 & 3 & 0 \\
\hline Regions & 4.02 & 1.74 & 1 & 4 & 6 & 0 \\
\hline
\end{tabular}

Notes: This table reports summary statistics of key variables. We use sampling weights to ensure that our statistics are representative of the population. 
consumer goods (excluding food), 3 per cent to solve problems with the law enforcement authorities such as the traffic police or customs, 3 per cent to speed up bureaucratic procedures with the public administration, 3 per cent to deal with the legal services and the courts, 2 per cent to gain access to education such as places in higher education or obtain a degree or diploma, 2 per cent to gain access to their hobbies or entertainment, travel tickets and so forth, 2 per cent communicate with local authorities on business matters such as delaying a tax payment, and 1 per cent to access tickets for events, the theatre or concerts.

When it is recognised that not all respondents needed to obtain these services in the past 12 months (e.g., medical services, finding a job, solving problems with the law enforcement authorities), vruzki appears to be commonly used to get things done. Indeed, for future research, enumerating whether respondents had engaged with these realms in the past year before asking them whether vruzki had been used, would be useful so as to evaluate the proportion of instances in which vruzki is used. Here, therefore, it can only be concluded that vruzki appears to be very commonly used when gaining access to medical services, finding a job, dealing with legal services and the courts, and accessing education, which are activities that only a relatively small proportion would have accessed in the year prior to the survey, and less commonly used when acquiring foodstuffs and consumer goods, which are activities that most would have engaged in during the year prior to the survey.

Who, therefore, uses vruzki in order to get things done in Bulgaria? Table 2 estimates a logit model and calculates the average marginal effects. This investigates whether individual socio-demographic, socioeconomic and spatial variables are significantly associated when other variables are taken into account and held constant. For continuous independent variables, the average marginal effects provide a good approximation to the probability of the change in vruzki that will be impacted by a one-unit change in the variable. And, varying one dummy variable from ' 0 ' to ' 1 ' changes the mean probability, taking into account all explanatory variables. Starting with the socio-demographic variables, this reveals that there are no significant gender variations in the use of vruzki. However, age does have a significant influence on its usage; younger age groups are more likely to use vruzki than older age groups. So too are larger households with four or more adults more likely to use connections

Table 2: Marginal effects after logit estimate of the propensity to use personal connections in Bulgaria

\begin{tabular}{|c|c|c|c|}
\hline & $\begin{array}{c}\text { Model } 1 \\
\text { Marginal effect } \\
\text { (Standard error) }\end{array}$ & $\begin{array}{c}\text { Model } 2 \\
\text { Marginal effect } \\
\text { (Standard error) }\end{array}$ & $\begin{array}{c}\text { Model } 3 \\
\text { Marginal effect } \\
\text { (Standard error) }\end{array}$ \\
\hline \multirow[t]{2}{*}{ Women } & -0.010 & -0.011 & -0.009 \\
\hline & $(0.022)$ & $(0.022)$ & $(0.022)$ \\
\hline \multirow[t]{2}{*}{ Age } & $-0.003^{* * *}$ & $-0.003^{* * *}$ & $-0.003^{* * *}$ \\
\hline & $(0.001)$ & $(0.001)$ & $(0.001)$ \\
\hline \multicolumn{4}{|l|}{ Marital status: (BG: Married/Remarried) } \\
\hline \multirow[t]{2}{*}{ - Cohabitating } & 0.010 & 0.000 & 0.008 \\
\hline & $(0.033)$ & $(0.032)$ & $(0.033)$ \\
\hline \multirow[t]{2}{*}{ - Single } & 0.049 & $0.049 *$ & 0.048 \\
\hline & $(0.030)$ & $(0.030)$ & $(0.030)$ \\
\hline \multicolumn{4}{|l|}{ Household Size: (BG: One Person) } \\
\hline \multirow[t]{2}{*}{-Two } & 0.048 & 0.050 & 0.049 \\
\hline & $(0.038)$ & $(0.038)$ & $(0.038)$ \\
\hline \multirow[t]{2}{*}{ - Three } & 0.038 & 0.037 & 0.036 \\
\hline & $(0.040)$ & $(0.040)$ & $(0.040)$ \\
\hline \multirow[t]{2}{*}{ - Four or more } & $0.078^{*}$ & $0.080^{* *}$ & $0.080^{*}$ \\
\hline & $(0.040)$ & $(0.041)$ & $(0.041)$ \\
\hline \multicolumn{4}{|l|}{ Employment status: (BG: Unemployed) } \\
\hline \multirow[t]{2}{*}{ - Self-employed } & -0.067 & -0.065 & -0.066 \\
\hline & $(0.070)$ & $(0.071)$ & $(0.071)$ \\
\hline \multirow[t]{2}{*}{ - Employed } & $-0.166^{* * *}$ & $-0.168^{* * *}$ & $-0.168^{* * *}$ \\
\hline & $(0.049)$ & $(0.049)$ & $(0.049)$ \\
\hline \multirow[t]{2}{*}{ - Other (Retired, students, disabled, etc.) } & $-0.139 * * *$ & $-0.142^{* * *}$ & $-0.137^{* * *}$ \\
\hline & $(0.044)$ & $(0.044)$ & $(0.044)$ \\
\hline
\end{tabular}


Table 2: Continued

\begin{tabular}{|c|c|c|c|}
\hline \multicolumn{4}{|c|}{ Financial situation (BG: Very comfortable) } \\
\hline \multirow[t]{2}{*}{ - Just comfortable } & $-0.218^{* *}$ & $-0.204^{* *}$ & $-0.218^{* *}$ \\
\hline & $(0.101)$ & $(0.102)$ & $(0.101)$ \\
\hline \multirow[t]{2}{*}{ - Maintaining } & $-0.212^{* *}$ & $-0.203^{* *}$ & $-0.219 * *$ \\
\hline & $(0.101)$ & $(0.102)$ & $(0.101)$ \\
\hline \multirow[t]{2}{*}{ - Struggling } & -0.165 & -0.156 & $-0.172^{*}$ \\
\hline & $(0.104)$ & $(0.105)$ & $(0.104)$ \\
\hline \multicolumn{4}{|c|}{ Personal income (BG: No income) } \\
\hline \multirow[t]{2}{*}{ - Less than 350 euros } & 0.057 & 0.046 & 0.051 \\
\hline & $(0.039)$ & $(0.040)$ & $(0.039)$ \\
\hline \multirow[t]{2}{*}{$-350-700$ euros } & $0.085^{* *}$ & $0.075^{*}$ & $0.082^{*}$ \\
\hline & $(0.043)$ & $(0.044)$ & $(0.043)$ \\
\hline \multirow{2}{*}{ - 700-1000 euros } & $0.102^{*}$ & $0.098^{*}$ & $0.100^{*}$ \\
\hline & $(0.054)$ & $(0.055)$ & $(0.055)$ \\
\hline \multirow[t]{2}{*}{$-1000-1300$ euros } & $0.124^{*}$ & $0.125^{*}$ & $0.124^{*}$ \\
\hline & $(0.065)$ & $(0.066)$ & $(0.065)$ \\
\hline \multirow[t]{2}{*}{ - 1300-1800 euros } & $0.257^{* *}$ & $0.268^{* *}$ & $0.263^{* *}$ \\
\hline & $(0.114)$ & $(0.115)$ & $(0.114)$ \\
\hline \multirow[t]{2}{*}{ - More than 1800 euros } & $0.371^{* *}$ & $0.371^{* * *}$ & $0.363^{* *}$ \\
\hline & $(0.148)$ & $(0.143)$ & $(0.145)$ \\
\hline \multicolumn{4}{|c|}{ Locality type: (BG: Rural area) } \\
\hline \multirow[t]{2}{*}{ - Small/medium town } & 0.034 & 0.027 & 0.028 \\
\hline & $(0.028)$ & $(0.028)$ & $(0.028)$ \\
\hline \multirow[t]{2}{*}{ - City } & $0.056^{* *}$ & $0.055^{* *}$ & $0.057^{* *}$ \\
\hline & $(0.025)$ & $(0.025)$ & $(0.025)$ \\
\hline \multicolumn{4}{|c|}{ Regions (BG: North Central) } \\
\hline \multirow[t]{2}{*}{ - North Eastern } & $-0.140^{* * *}$ & $-0.117^{* * *}$ & $-0.136^{* * *}$ \\
\hline & $(0.042)$ & $(0.041)$ & $(0.042)$ \\
\hline \multirow[t]{2}{*}{ - North Western } & $0.154^{* * *}$ & $0.182^{* * *}$ & $0.174^{* * *}$ \\
\hline & $(0.048)$ & $(0.049)$ & $(0.049)$ \\
\hline \multirow[t]{2}{*}{ - South Central } & $0.116^{* * *}$ & $0.140^{* * *}$ & $0.126^{* * *}$ \\
\hline & $(0.041)$ & $(0.040)$ & $(0.041)$ \\
\hline \multirow[t]{2}{*}{ - South Eastern } & 0.058 & $0.085^{*}$ & 0.065 \\
\hline & $(0.045)$ & $(0.044)$ & $(0.045)$ \\
\hline \multirow[t]{2}{*}{ - South Western } & $-0.121^{* * *}$ & $-0.116^{* * *}$ & $-0.126^{* * *}$ \\
\hline & $(0.038)$ & $(0.037)$ & $(0.038)$ \\
\hline \multirow[t]{2}{*}{ Tax morale } & $0.018^{* * *}$ & $0.016^{* * *}$ & $0.016^{* * *}$ \\
\hline & $(0.006)$ & $(0.006)$ & $(0.006)$ \\
\hline \multicolumn{4}{|c|}{ Detection risk (BG: Very small/ Fairly small) } \\
\hline \multirow[t]{2}{*}{ - Fairly high/Very high } & $-0.067^{* *}$ & & $-0.066^{* *}$ \\
\hline & $(0.028)$ & & $(0.029)$ \\
\hline \multicolumn{4}{|c|}{ Expected sanctions (BG: contributions due) } \\
\hline - Plus a fine/ Prison & & $-0.065^{* *}$ & $-0.064^{* *}$ \\
\hline & & $(0.028)$ & $(0.028)$ \\
\hline Number of imputation & 50 & 50 & 50 \\
\hline $\mathrm{N}$ & 2005 & 2005 & 2005 \\
\hline
\end{tabular}

$*^{* *},{ }^{* *}$, and * indicate significance at the 1,5 and 10 percent level respectively.

Source: authors' calculations from GREY survey

to get things done than single person households. Turning to the socio-economic variables, the finding is that the employed and economically inactive are significantly less likely than the unemployed to use connections, as are those reporting their financial situation as struggling, maintaining or comfortable 
significantly less likely to use connections than those reporting their financial situation as very comfortable. Similarly, the higher is the personal formal income of a respondent, the more likely they are to use vruzki to get things done. Indeed, those earning over $€ 1800$ are 36.3 per cent more likely to have used vruzki in the past 12 months than those with no formal income. The use of vruzki is also significantly higher in urban than rural areas, and there are also significant regional variations in its usage.

Turning to the explanations and policy approaches for tackling the use of connections, we include risk of detection and level of penalties separately in columns 1 and 2 . In column 3 we include them together in the model. The results remain the same. Models 1 and 3 reveal that those perceiving high risk are less likely to use connections to circumvent formal procedures, confirming the rational actor thesis. Based on the magnitude of the marginal effects in model 3, we find that those who perceive high risk (fairly high/very high) in comparison to those who perceive low risk (very small/fairly small) have $6.7 \%$ lower probability to be engaged in vruzki. In addition, models 2 and 3 reveals that those perceiving the sanctions to be higher are less likely to use connections to get things done. This, therefore, suggests that increasing penalties will reduce the likelihood of people using connections to get things done, as will increasing the risks of detection. For the variable of tax morale, the finding is that the greater is the asymmetry between citizens' norms, values and beliefs, and the formal rules and regulations, the greater is the likelihood of using vruzki to get things done, thus confirming the social actor explanation and suggesting that tackling the asymmetry between formal and informal institutions might be an effective policy approach. As a robustness check, an OLS model was estimated to see if the results are consistent. This was the case, providing further support for these findings.

\section{DISCUSSION AND CONCLUSIONS}

This paper has evaluated whether the social practice of using personal networks to circumvent formal procedures, known as vruzki, is prevalent in Bulgaria and who uses such connections. Reporting a survey of 2,005 respondents conducted in late 2015, the finding is that 30 per cent of respondents had used vruzki in the past 12 months to get things done, particularly when accessing medical services or finding a job. Estimating a logit model and then calculating the marginal effects, the population groups significantly more likely to have used vruzki are those whose norms, values and beliefs are not in symmetry with the formal laws and regulations, those reporting their financial situation as very comfortable, and the highest income groups, but also younger people, the unemployed, and those living in larger households. A limitation of this research is that respondents were not asked whether they had engaged with these realms in the past year before asking them whether vruzki had been used. For future research, this would be useful so as to evaluate the proportion of instances in which vruzki is used.

Nevertheless, theoretically, and when explaining the use of vruzki, this paper has evaluated the rational economic actor and social actor perspectives, derived from the study of undeclared work. This has revealed some support for the rational economic actor perspective that citizens engage in such endeavour when the benefits outweigh the costs. Increasing the penalties for engaging in such illicit activity and the risks of detection reduces the likelihood of people using connections to get things done. Moreover, strong support is found for the social actor approach. There is a strong statistically significant correlation between the use of vruzki and the level of institutional asymmetry; the greater is the asymmetry between citizens' norms, values and beliefs, and the formal rules and regulations, the greater is the likelihood of using vruzki to get things done. This suggests that beyond a deterrence approach, tackling the asymmetry between formal and informal institutions is required in order to tackle this endeavour.

How, therefore, can this illicit social practice be tackled? This has not before been considered in any known studies. Several policy options are available. On the one hand, governments can pursue its eradication using tougher penalties and increasing the risks of detection, although whether the political will exists to do this is open to question. On the other hand, it can be also tackled by reducing the asymmetry between formal and informal institutions. To achieve this, firstly, attempts can be made to change the norms, values and beliefs of citizens (i.e., the informal institutions) regarding the acceptability of such an illicit practice, such as by running awareness raising campaigns about the negative consequences of vruzki and the positive consequences of adopting meritocratic values across society. Secondly, it can also be pursued by modernising the formal institutions so as to reduce the formal institutional inefficiencies and imperfections that lead to vruzki being used. None of these are mutually exclusive approaches, and can be sequenced in different ways such as by organising an awareness raising campaign alongside improving modernising public services so as to reduce the 
circumvention of formal procedures, and then following this up with tougher penalties for those who still engage in these practices that result in nepotism, cronyism and corruption. Whether this is the appropriate sequencing has not so far been evaluated.

What is certain, however, is that on the whole, the use of vruzki cannot continue in a modern meritocratic society and doing nothing is not an option. Although there might be particular instances where this practice could be seen as positive and beneficial, it is on the whole a practice that results in nepotism, cronyism and corruption, and prevents the advent of meritocratic allocation practices. If this paper therefore stimulates research on its prevalence and distribution across a wider array of countries, as well as greater debate on what needs to be done to eradicate this practice, including a two-way and three-way analysis of the interaction effects between the different policy measures, which is a limitation of the current research, then it will have achieved its intention.

\section{REFERENCES}

Al Ramahi, A. 2008. Wasta in Jordan: a distinct feature of (and benefit for) Middle eastern society. Arab Law Quarterly 22 (1): 35-62.

Allingham, M. and Sandmo, A. 1972. Income tax evasion: a theoretical analysis. Journal of Public Economics 1: 323-38.

Ardichvili A., Jondle, D., Kowske, B., Cornachione, E. Li, J. and Thakadipuram, T. 2010. Ethical business practices in BRICs: comparing perceptions of managers and employees in Brazil, Russia, India and China, and G7 Nations. Paper presented at Society for Business Ethics Annual Meeting, March

Arnstberg, K. and Boren, T. 2003. Everyday Economy in Russia, Poland and Latvia. Stockholm: Södertörns Högskola.

Ayios, A., Jeuirssen, R., Manning, P. and Spence, L. J. 2014. Social capital: a review from an ethics perspective. Business Ethics: a European Review 23 (1): 108-124.

Bailey, D. C. 2012. Women and wasta: the use of focus groups for understanding social capital and Middle Eastern women. The Qualitative Report 17 (65): 1-18.

Barnett, A., Yandle, B. and Naufal, G. 2013. Regulation, trust and cronyism in Middle Eastern societies: the simple economics of 'wasta'. Journal of Socio-Economics 44 (1): 41-46.

Chavdarova, T. 2013. Institutionalisation of market order and reinstitutionalisation of Vruzki (connections). In Informality in Eastern Europe: Structures, Political Cultures and Social Practices, edited by C. Giordano and N. Hayoz, 179-196. Bern: Peter Lang.
Chen, C. C., Chen, X-P. and Huang, S. 2012. Chinese guanxi: an integrative review and new directions for future research. Management and Organization Review 9 (1): 167-207.

Chen, Y., Friedman, R., Yu, E. and Sun, F. 2011. Examining the positive and negative effects of guanxi practices: a multi-level analysis of guanxi practices and procedural justice perceptions. Asia Pacific Journal of Management 28: 715-735.

Ferreira, M. C., Fischer, R., Barreiros Porto, J., Pilati, R. and Milfont, T. L. 2012. Unravelling the hystery of Brazilian Jeitinho: a cultural exploration of social norms. Personality and Social Psychology Bulletin 38 (3): 331-44.

Garigiulo, M. and Benassi, M. 1997. The dark side of social capital. In Corporate Social Capital and Liability, edited by R. A. J. Leenders and S. M. Gabbay, 290-322. Munich: Springer.

Giddens, A. 1998. The Third Way: the renewal of social democracy. Cambridge: Polity.

Gittell, R. and Vidal, A. 1998. Community Organizing: building social capital as a development strategy. London: Sage.

Gordeev, V. G., Pavlova, M. and Groot, W. 2014. Informal payments for health care services in Russia: old issue in new realities. Health Economics, Policy and Law 9 (1): 25-48.

Gough, I. 2000. Global Capital, Human Needs and Social Policies. Basingstoke: Palgrave.

Granovetter, M. 1973. The strength of weak ties. American Journal of Sociology 78 (6): 1360-1380.

Gu, F. F., Hung, K. and Tse, D. K. 2008. When does guanxi matter? Issues of capitalization and its dark sides. Journal of Marketing 72 (4): 12-28.

Helmke, G. and Levitsky, S. 2004. Informal institutions and comparative politics: a research agenda. Perspectives on Politics 2: 725-740.

Hsiung, B. 2013. Guanxi: personal connections in Chinese society. Journal of Bioeconomics 15 (1): 17-40.

Kaitelidou, D. C., Tsirona, C. C., Galanis, P. A., Siskou, O., Mladovsky, P., Kouli, E. G., Prezerakos, P. E., Theodorou, M., Sourtzi, P. A. and Liaropolous, L. L. 2013. Informal payments for maternity health services in public hospitals in Greece. Health Policy 109 (1): 23-40.

Kilani, S. and Sakijha, B. 2002. Wasta: the declared secret. Ammam: Arab Archives Institute.

Kline, P. 2000. The handbook of psychological testing. London: Routledge.

Ledeneva, A. V. 2006. How Russia really works: the informal practices that shaped post-Soviet politics and business. New York: Cornell University Press.

Ledeneva, A. V. 2008. Blat and guanxi: informal practices in Russia and China. Comparative Studies in Society and History 50 (1): 118-144. 
Ledeneva, A. V. 2009. From Russia with blat: can informal networks help modernize Russia? Social Research 76 (1): 257-288.

Ledeneva, A. V. 2013. Can Russia Modernise? Sistema, power networks and informal governance. Cambridge: Cambridge University Press.

Luo, J-D. 2011. Guanxi revisited: an exploratory study of familiar ties in a Chinese workplace. Management and Organization Review 7 (2): 329-351.

Luo, Y., Huang, Y. and Lu Wang, S. 2011. Guanxi and organisational performance: a meta-analysis. Management and Organization Review. 8 (1): 139-172.

Mellahi, K. and Wood, G. T. 2003. From kinship to trust: changing recruitment practices in unstable political contexts. International Journal of Cross-Cultural Management Vol. 3: 369-381.

Michailova S. and Worm V. 2003. Personal Networking in Russia and China: blat and Guanxi. European Management Journal 21 (4): 509-519.

Mohamed, A. A. and Mohamed, M. S. 2011. The effect of wasta on perceived competence and morality in Egypt. Cross Cultural Management 18 (4): 412-425.

Munro, N., Duckett. J., Hunt, K. and Sutton, M. 2013. The use of guanxi and other strategies in dealing with the Chinese health care system. Paper presented at the Association for Asian Studies Meeting, San Diego 20-24 March.

Onoshchenko, O. and Williams, C. C. 2013. Paying for favours: evaluating the role of blat in post-Soviet Ukraine. Debatte: Journal of Contemporary Central and Eastern Europe 21 (2-3): 259-277.

Polanyi, K. 1944. The Great Transformation. Boston: Beacon Press.

Putnam, R. 2000. Bowling alone: the collapse and revival of American community. New York: Simon and Schuster.

Putzel, J. 1997. Accounting for the 'dark side' of social capital: reading Robert Putnam on democracy. Journal of International Development 9 (7): 939-949.

Schulman, M. D. and Anderson, C. 2009. The dark side of the force: a case study of restructuring and social capital. Rural Sociology 64 (3): 351-372.

Shou, Z., Chen, J., Zhu, W. and Yang, L. 2014. Firm capability and performance in China: the moderating role of guanxi and institutional forces in domestic and foreign contexts. Journal of Business Research 67 (2): 77-82.

Smith, P., Huang, H. J., Harb, C. and Torres, C. 2012. How distinctive are indigenous ways of achieving influence? A comparative study of guanxi, wasta, jeitinho, svyazi and pulling strings. Journal of Cross-Cultural Psychology 43 (1): 135-150.

Smith, P., Torres, C., Leong, C. H., Budhwar, P., Achoui, M. and Lebedeva, N. 2011. Are indigenous approaches to achieving influence in business organizations distinctive? A comparative study of guanxi, wasta, jeitinho, svyazi and pulling strings. International Journal of Human Resource Management 23 (2): 333-348.

Stack, R. 1974. All Our Kin: strategies for survival in a black community. New York: Harper and Row.

Stepurko, T., Pavolova, M., Levenets, O., Gryga, I and Groot, W. 2013. Informal patient payments in maternity hospitals in Kiev, Ukraine. International Journal of Health Planning and Management 28 (2): 169-187.

Thompson, G., Frances, J., Lavacic, R. and Mitchell, J. 1991 (Eds.) Markets, Hierarchies and Networks. London: Sage.

Tlaiss, H. and Kauser, S. 2011. The importance of wasta in the career success of Middle Eastern managers. Journal of European Industrial Training 35 (5): 467-486.

Williams, C. C. and Franic, J. 2015. Tackling the propensity towards undeclared work: some policy lessons from Croatia. The South East European Journal of Economics and Business 10 (1): 18-31.

Williams, C. C. and Horodnic, I. A. 2015a. Evaluating the prevalence of the undeclared economy in Central and Eastern Europe: an institutional asymmetry perspective. European Journal of Industrial Relations 21 (4): 389-406.

Williams, C. C. and Horodnic, I. A. 2015b. Who participates in the undeclared economy in South-Eastern Europe? an evaluation of the marginalization thesis. South-Eastern Europe Journal of Economics 13 (2): 157-175.

Williams, C. C. and Horodnic, I. A. 2017. Evaluating the illegal employer practice of under-reporting employees' salaries. British Journal of Industrial Relations, DOI: 10.1111/ bjir.12179

Williams, C. C. and Onoshchenko, O. 2014a. Evaluating the role of blat in finding graduate employment in post-Soviet Ukraine: the 'dark side' of job recruitment? Employee Relations 36 (3): 254-265.

Williams, C.C. and Onoshchenko, O. 2014b. Evaluating the prevalence and nature of blat in post-Soviet societies: a case study of the education sector in Ukraine. International Journal of Social Economics 41 (9): 747-759.

Williams, C. C. and Padmore, J. 2013a. Evaluating the prevalence and distribution of quasi-formal employment in Europe. Relations Industrielles/Industrial Relations 68 (1): 71-95.

Williams, C. C. and Padmore, J. 2013b. Envelope wages in the European Union. International Labour Review 152 (3-4): 411-430.

Williams, C. C., Round, J. and Rodgers, P. 2013. The role of informal economies in the post-Soviet world: the end of transition? London: Routledge.

Williams, C. C., Franic, J. and Dzhekova, R. 2014. Explaining and tackling the undeclared economy in Bulgaria: an institutional asymmetry perspective. The South-East European Journal of Economics and Business 9 (2): 33-45.

Williams, C. C., Horodnic, A. and Horodnic, I. 2016. Who is giving informal payments for public healthcare in EastCentral Europe? an evaluation of socio-economic and 
spatial variations. Eastern Journal of European Studies 7 (1): 49-61.

Williams, N. and Vorley, T. 2015. Institutional asymmetry: how formal and informal institutions affect entrepreneurship in Bulgaria. International Small Business Journal 33 (8): 840-861.

Yahiaoui, D. and Zoubir, Y. H. 2006. HRM in Tunisia. In Managing Human Resources in the Middle East, edited by P. S. Budhwar and K. Mellahi, 235-249. London: Routldege.

Yang, Z. and Wang, C. L. 2011. Guanxi as a governance mechanism in business markets: its characteristics, relevant theories, and future research directions. Industrial Marketing Management 40: 492-495.

Young, M. and Wilmott, P. 1975. The Symmetrical Family: a study of work and leisure in the London region. Harmondsworth: Penguin.

Zhan, J. V. 2012. Filling the gap of formal institutions: the effects of Guanixi network on corruption in reform-era China. Crime, Law and Social Change, 58: 93-109.

Zhuang, G., Xi, Y. and Tsang, A. S. L. 2010. Power, conflict and cooperation: the impact of guanxi in Chinese marketing channels. Industrial Marketing Management 39: 137-149. 